\title{
ANALISIS POTENSI MASYARAKAT "UMA LENGGE" DI DESA MARIA WAWO KABUPATEN BIMA SEBAGAI DESA WISATA (TOURISM VILLAGE)
}

\author{
Adi Hidayat Argubi ${ }^{1}$, Ruli Inayah Ramadhoan ${ }^{2}$, Tauhid ${ }^{3}$ \\ Sekolah Tinggi Ilmu Sosial dan Ilmu Politik (STISIP) Mbojo ${ }^{1}$ \\ Email: adi.hidayat@stisipbima.ac.id \\ Universitas Muhammadiyah Malang ${ }^{2}$ \\ Email: ruliramadhoan@gmail.com \\ Sekolah Tinggi Ilmu Sosial dan Ilmu Politik (STISIP) Mbojo ${ }^{3}$ \\ Email: tauhid@stisipbima.ac.id
}

\begin{abstract}
The purpose of this research is to find out the various potential attractions of the Uma Lengge tourist attraction Maria Wawo Village in Maria Village, Wawo Bima sub-district as a tourist village. This type of research used in this research is descriptive research. This research was conducted in Maria Village, Wawo Sub-district, Bima District. The stages of data collection are observation, structured interviews, questionnaires, and literature study. While the data analysis method used is descriptive qualitative, SWOT, and value scale analysis. The results showed that the potential of Wawo Tourism Village as one of the attractions in Bima Regency was physical potential that included "Uma Lengge" (Bima traditional house), typical rural natural scenery, Wawo village museums and Wawo Tourism Village recreation parks. Whereas its non-physical potential is Wawo culture, art, community activities in Wawo tourism village. Facilities that are available in Wawo Tourism Village are a resting place or shelter, parking area, toilets / toilets and worship facilities in the form of a small mosque. The final results of the perception of the public and tourists showed a positive support for the development of the Tourism Village Wawo as one of the cultural tourism objects in the Regency of Bima.
\end{abstract}

\section{Keyword: Village Tourism}

\begin{abstract}
Abstrak
Tujuan penelitian ini untuk mengetahui berbagai potensi objek wisata Uma Lengge Desa Maria Wawo di Desa Maria kecamatan Wawo Bima sebagai desa wisata. Jenis penelitian yang dipakai dalam penelitian ini adalah penelitian deskriptif. Penelitian ini dilakukan di Desa Maria kecamatan Wawo kabupaten Bima. Tahapan pengumpulan data adalah dengan observasi, wawancara berstruktur, kuesioner, dan studi kepustakaan. Sedangkan metode analisa data yang digunakan adalah deskriptif kualitatif, SWOT, dan analisis skala nilai. Hasil penelitian menunjukkan bahwa potensi Desa Wisata Wawo sebagai salah satu objek wisata di Kabupaten Bima adalah potensi fisik yang meliputi "Uma Lengge" (rumah tradisional Bima), pemandangan alam khas pedesaan, musium desa Wawo dan taman rekreasi/wisata Desa Wisata Wawo. Sedangkan potensi nonfisiknya adalah kebudayaan Wawo, kesenian, kegiatan masyarakat desa wisata Wawo. Fasilitas yang sudah tersedia di objek Desa Wisata Wawo adalah tempat istirahat atau shelter, areal parkir, toilet/MCK dan fasilitas peribadatan berupa musholla. Hasil akhir persepsi dari masyarakat maupun wisatawan menunjukkan adanya dukungan yang positif terhadap pengembangan Desa Wisata Wawo sebagai salah satu objek wisata budaya di Kabupaten Bima.
\end{abstract}

Kata Kunci: Village Tourism 


\section{INTRODUCTION}

Kabupaten Bima NTB merupakan kota transit wisata bagi wisatawan yang akan berkunjung ke pulau Komodo. Identitas sebagai kota transit wisata ini sedikit banyak membawa pengaruh besar terhadap kebijakan pengembangan pariwisata daerah kabupaten Bima. Salah satu objek wisata yang diminati oleh wisatawan baik mancanegara maupun domestik adalah "Uma Lengge" yang ada di desa Maria, kecamatan Wawo, kabupaten Bima NTB. "Uma Lengge" merupakan hasil budaya masyarakat Wawao berupa bangunan rumah tradisional tempat menyimpan hasil panen masyarakat setiap datangnya musim panen. Yang menarik bagi wisatawan tidak hanya bentuk bangunan rumah tradisonal "Uma Lengge" saja tapi aktifitas dan budaya masyarakat "Uma Lengge" yang khas dan unik. Sejarah panjang "Uma Lengge" masih ditradisikan oleh masyarakatnya dari generasi ke generasi melalui aktivitas sosial dan budaya masyarakat. Budaya khas inilah yang tidak dimiliki oleh daerah atau objek wisata lainnya di kabupaten Bima. Lokasi "Uma Lengge" yang dekat dengan perbatasan penyebrangan menuju pulau Komodo menjadikan objek wisata ini menjadi objek wajib yang harus dikunjungi oleh wisatawan. Peluang iinilah yang belum mampu dikelola dengan baik oleh pemerintah daerah kabupaten Bima. Budaya "Uma Lengge" merupakan aset wisata yang harus dipelihara agar tidak punah dan hilang bersama-sama dengan perkembangan jaman. Oleh karena itu upaya-upaya untuk mempertahankan "Uma Lengge" sebagai aset budaya menjadi penting dilakukan pemerintah daerah.

Potensi wisata "Uma Lengge" tidak hanya pada aspek bangunan rumah tradisional "Uma Lengge" dan aktifitas dan budaya masyarakat "Uma Lengge" yang khas dan unik akan tetapi juga didukung oleh pesona alam puncak yang indah dan dingin. Kakayaan potensi wisata ini akan menghasilkan sesuatu baik bagi penerimaan PAD maupun bagi peningkatan ekonomi dan kesejahteraan masyarakat sebagai akibat pengembangan sektor wisata apabila potensi wisata "Uma Lengge" ini dapat dioptimalkan menjadi daya tarik wisata. Upaya-upaya pengembangan pariwisata yang memungkinkan untuk dilakukan mengingat potensi dan kekhasan wisata "Uma Lengge" adalah dengan mengembangkan desa wisata (Tourism Village).

Pembangunan Desa Wisata di Desa Maria Bima dapat menjadi media promosi untuk produk lokal, dan membantu perkembangan regional dalam memasarkan usaha dan menciptakan nilai tambah dan "direct-marking" merangsang kegiatan ekonomi dan memberikan manfaat kepada masyarakat lokal di sekitar Objek Wisata. Dasar pemikiran inilah yang melatarbelakangi kenapa analisis potensi masyarakat "Uma Lengge" di Desa Maria Wawo sebagai Desa Wisata (Tourism Village) menjadi penting dilakukan untuk menemukan model perancangan pengembangan pariwisata yang cocok dengan kondisi dan potensi yang dimiliki oleh objek wisata dan masyarakat "Uma Lengge" di Desa Maria Wawo kabupaten Bima NTB.

\section{METODOLOGI}

Penelitian ini mengunakan metode deskriptif.Dalam penelitian ini populasinya adalah masyarakat Desa Maria Kecamatan Wawo Kabupaten Bima.Teknik pengambilan sampel adalah proporsional randomsampling sebanyak $10 \%$ dari jumlah populasi berdasarkan mata pencahariansedangkan jumlah sampel wisatawan diambil dengan quota sampling sebanyak 50 responden. Teknik pengumpulan data dalam penelitian ini selain menggunakan metode observasi, wawancara berstruktur, studi kepustakaan dan kuesioner. Sedangkan teknik analisis 
data menggunakan analisis deskriptif dan statistik untuk menganalisis kecenderungan persepsi masyarakat terkait potensi objek wisata Uma Lengge Desa Maria Wawo di Desa Maria kecamatan Wawo Bima sebagai desa wisata yang diolah dari data kuesioner serta analisis SWOT untuk menganalisis kondisi eksternal (external faktor) dan kondisi internal (internal factor)potensi objek wisata Uma Lengge Desa Maria Wawo di Desa Maria kecamatan Wawo Bima sebagai desa wisata.

\section{Definisi Operasional Pendekatan Pengembangan Desa Wisata}

Menurut Nuryanti (1993) "Desa wisata adalah suatu bentuk integrasi antara atraksi, akomodasi dan fasilitas pendukung yang disajikan dalam suatu struktur kehidupan masyarakat yang menyatu dengan tata cara dan tradisi yang berlaku". Komponen Utama Desa Wisata Terdapat dua konsep yang utama dalam komponen desa wisata : 1). Akomodasi : sebagian dari tempat tinggal para penduduk setempat dan atau unit-unit yang berkembang atas konsep tempat tinggal penduduk 2). Atraksi : seluruh kehidupan keseharian penduduk setempat beserta setting fisik lokasi desa yang memungkinkan berintegrasinya wisatawan sebagai partisipasi aktif seperti : kursus tari, bahasa dan lain-lain yang spesifik.

Sedangkan Inskeep (1997) memberikan definisi desa wisata "Village Tourism, where small groups of tourist stay in or near traditional, often remote villages and learn about village life and the local environment".(Wisata pedesaan di mana sekelompok kecil wisatawan tinggal dalam atau dekat dengan suasana tradisional, sering di desa-desa yang terpencil dan belajar tentang kehidupan pedesaan dan lingkungan setempat).

Pengembangan dari desa wisata harus direncanakan secara hati-hati agar dampak yang timbul dapat dikontrol. Berdasar dari penelitian dan studi-studi dari UNDP/WTO dan beberapa konsultan
Indonesia, dicapai dua pendekatan dalam menyusun rangka kerja/konsep kerja dari pengembangan sebuah desa menjadi desa wisata.Menurut UNDP and WTO. (1981) Pendekatan pasar untuk pengembangan desa wisata ada tiga:

a. Interaksi tidak langsung. Model pengembangan didekati dengan cara bahwa desa mendapat manfaat tanpa interaksi langsung dengan wisatawan. Bentuk kegiatan yang terjadi semisal: penulisan buku-buku tentang desa yang berkembang, kehidupan desa, arsitektur tradisional, latar belakang sejarah, pembuatan kartu pos dan sebagainya.

b. Interaksi setengah langsung. Bentukbentuk one day trip yang dilakukan oleh wisatawan, kegiatan-kegiatan meliputi makan dan berkegiatan bersama penduduk dan kemudian wisatawan dapat kembali ke tempat akomodasinya. Prinsip model tipe ini adalah bahwa wisatawan hanya singgah dan tidak tinggal bersama dengan penduduk.

c. Interaksi Langsung. Wisatawan dimungkinkan untuk tinggal/bermalam dalam akomodasi yang dimiliki oleh desa tersebut. Dampak yang terjadi dapat dikontrol dengan berbagai pertimbangan yaitu daya dukung dan potensi masyarakat setempat. Alternatif lain dari model ini adalah penggabungan dari model pertama dan kedua.

Menurut Nuryanti (1993) " selain pendekatan pasar, pengembangan desa wisata dapat dilakukan dengan Pendekatan Fisik Desa Wisata. Pendekatan ini merupakan solusi yang umum dalam mengembangkan sebuah desa melalui sektor pariwisata dengan menggunakan standar-standar khusus dalam mengontrol perkembangan dan menerapkan aktivitas konservasi. Pengembangan dengan pendekatan fisik adalah sebagai berikut:

1) Mengonservasi sejumlah rumah yang memiliki nilai budaya dan arsitektur yang tinggi dan 
mengubah fungsi rumah tinggal menjadi sebuah museum desa untuk menghasilkan biaya untuk perawatan dari rumah tersebut. Contoh pendekatan dari tipe pengembangan model ini adalah Desa Wisata di Koanara, Flores. Desa wisata yang terletak di daerah wisata Gunung Kelimutu ini mempunyai aset wisata budaya berupa rumah-rumah tinggal yang memiliki arsitektur yang khas. Dalam rangka mengkonservasi dan mempertahankan rumah-rumah tersebut, penduduk desa menempuh cara memuseumkan rumah tinggal penduduk yang masih ditinggali. Untuk mewadahi kegiatan wisata di daerah tersebut dibangun juga sarana wisata untuk wisatawan yang akan mendaki Gunung Kelimutu dengan fasilitas berstandar resor minimum dan kegiatan budaya lain.

2) Mengonservasi keseluruhan desa dan menyediakan lahan baru untuk menampung perkembangan penduduk desa tersebut dan sekaligus mengembangkan lahan tersebut sebagai area pariwisata dengan fasilitas-fasilitas wisata. Contoh pendekatan pengembangan desa wisata jenis ini adalah Desa Wisata Sade, di Lombok.

3) Mengembangkan bentuk-bentuk akomodasi di dalam wilayah desa tersebut yang dioperasikan oleh penduduk desa tersebut sebagai industri skala kecil. Contoh dari bentuk pengembangan ini adalah Desa wisata Wolotopo di Flores. Aset wisata di daerah ini sangat beragam antara lain: kerajinan tenun ikat, tarian adat, rumahrumah tradisional dan pemandangan ke arah laut. Wisata di daerah ini dikembangkan dengan membangun sebuah perkampungan skala kecil di dalam lingkungan
Desa Wolotopo yang menghadap ke laut dengan atraksi-atraksi budaya yang unik. Fasilitasfasilitas wisata ini dikelola sendiri oleh penduduk desa setempat. Fasilitas wisata berupa akomodasi bagi wisatawan, restaurant, kolam renang, peragaan tenun ikat, plaza, kebun dan dermaga perahu boat.

Karena bentuk wisata pedesaan yang khas maka diperlukan suatu segmen pasar tersendiri. Menurut Nuryanti (1993) "Terdapat beberapa tipe wisatawan yang akan mengunjungi desa wisata ini yaitu :

1) Wisatawan domestik; terdapat tiga jenis pengunjung domestik yaitu :

a) Wisatawan atau pengunjung rutin yang tinggal di daerah dekat desa tersebut. Motivasi kunjungan : mengunjungi kerabat, membeli hasil bumi atau barang-barang kerajinan. Pada perayaan tertentu, pengunjung tipe pertama ini akan memadati desa wisata tersebut.

b) Wisatawan dari luar daerah (luar propinsi atau luar kota), yang transit atau lewat dengan motivasi, membeli hasil kerajinan setempat.

c) Wisatawan domestik yang secara khusus mengadakan perjalanan wisata ke daerah tertentu, dengan motivasi mengunjungi daerah pedesaaan penghasil kerajinan secara pribadi.

2) Wisatawan Manca Negara ; terdapat tiga jenis pengunjung Mancanegara yaitu :

a) Wisatawan yang suka berpetualang dan berminat khusus pada kehidupan dan kebudayaan di pedesaan. Umumnya wisatawan ini tidak ingin bertemu dengan wisatawan lainnya dan berusaha mengunjungi kampung dimana tidak begitu banyak wisatawan asing. 
b) Wisatawan yang pergi dalam grup (di dalam suatu biro perjalanan wisata). Pada umumnya mereka tidak tinggal lama di dalam kampung dan hanya tertarik pada hasil kerajinan setempat.

c) Wisatawan yang tertarik untuk mengunjungi dan hidup di dalam kampung dengan motivasi merasakan kehidupan di luar komunitas yang biasa dihadapinya.

\section{RESULT AND DISCUSSION \\ Potensi Objek wisata Uma Lengge Desa Maria Wawo Sebagai Objek Wisata Potensi Fisik}

Objek wisata Objek wisata Uma Lengge Desa Maria Wawo merupakan objek wisata alam yang terletak di Desa Maria, kecamatan Wawo Kabupaten Bima, pada ketinggian $500 \mathrm{mdl}$ di atas permukaan laut dengan suhu udara $21-30$ derajat Celcius dan curah hujan 992 milimeter rata-rata setiap tahunnya, jarak antara objek wisata Budaya Uma Lengge Maria Wawo dengan jarak ke ibu kota kabupaten terdekat kira-kira sejauh 17 kilometer. Untuk mencapai lokasi objek wisata Uma Lengge Desa Maria Wawo dapat digunakan kendaraan roda dua maupun roda empat, pribadi atau transportasi umum seperti angkutan bus dan ojek yang tersedia di Desa Maria. Objek Wisata Uma Lengge berada di kawasan puncak yang berhawa dingin yang sangat cocok untuk kegiatan akhir pekan.

Kemudian upaya penataan objek wisata Uma Lengge Desa Maria Wawo terus dilakukan yaitu melalui peningkatan sarana dan prasarana pendukung kegiatan wisata. Sarana-sarana pendukung pariwisata Objek wisata Uma Lengge Desa Maria Wawo lain terus dibangun oleh pemerintah. Fasilitas pendukung tersebut sampai saat ini terdiri dari: a. Area Bangunan Tradisional Uma Lengge dan Jompa. Objek wisata Objek wisata Uma Lengge Desa Maria Wawo sangat cocok digunakan sebagai tempat istirahat atau refreshing bagi wisatawan. Di tempat ini disediakan tempat-tempat duduk bagi wisatawan yang ingin bersantai sambil menikmati hawa udara yang sejuk. Di objek wisata Uma Lengge ini terdapat kolam pemandian Oi Wobo lengkap dengan sarana dan prasarana pendukungnya, seperti tempat bilas, kamar mandi dan toilet.

b. Sanggar-Sanggar Kesenian Tradisonal. Objek wisata Uma Lengge Desa Maria Wawo juga didukung oleh keberadaan sanggar-sanggar seni yang dibina oleh mesyarakat desa dengan dukungan pemerintah kabupaten. Beberapa sanggar seni tradisional tersebut adalah sanggar seni Pusaka Tua, Jala Judi dan La Iha.

\section{Potensi Non fisik}

Potensi non fisik Objek Wisata Objek wisata Uma Lengge Desa Maria Wawo berupa kesenian tradisional maupun kehidupan tradisional masyarakat setempat. Adapun potensi nonfisik yang ada dan berpengaruh terhadap pengembangan objek ini meliputi:

a) Kebudayaan

1). Keunikan Budaya "Uma Lengge"

Uma Lengge adalah bangunan tradisonal masyarakat Desa Maria Kecamatan Wawo yang digunkan oleh masyarakat untuk menyimpan hasil panen. Menurut Ketua Adat Desa Maria, latar belakang dibangun atau dibuatnya Uma Lengge adalah karena pada tahun 1955 di desa Maria terjadi musibah yang paling besar yaitu terbakar hangusnya desa Nari yang menghabiskan semua rumah masyarakat. Dari kejadian inilah maka masyarakat desa Maria berkeinginan untuk membuat atau membangun Uma Lengge untuk menyimpan hasil pertaniannya. Sampai saat ini di obejk wisata Uma Lengge terdapat 12 unit Lengge dan 83 
unit Jompa yang masing-masing dimiliki oleh masyarakat.

\section{2). Keunikan Budaya dan Adat Istiadat}

Adat bagi masyarakat desa Maria adalah kebiasaan baik (adat istiadat) yang baik dalam sebuah komunitas (lingkungan) yang tidak boleh dilangar oleh siapapun. Apabila salah seseorang melakukan pelanggaran, maka yang bersangkutan harus di hukum, itulah yang di namakan Hukum Adat yang diterapkan di desa Maria Wawo. Hukum adat ini tajam dari hukum pidana dari sisi pelaksanaan keputusannya cepat diketahui dan tidak memakan biaya dan waktu. Begitu seseorang melakukan pelanggaran lalu proses pada saat dan waktu itu juga oleh ketua adat dan anggotanya. Maka hasil keputusan langsung diterima oleh pelangar hukum adat. Di zaman dahulu kala, 300 tahun yang sudah hukum adatlah yang berjalan di tiap lingkungan, karena begitu keras dan kejamnya hukum adat dan segala sesuatu yang bertentangan dengan adat itu sendiri disosialisasikan secara turun temurun dari anggota keluarga masingmasing bahwa adat itu benar-benar tidak boleh dilanggar oleh semua warga. Contohnya : 1). Tidak boleh mencuri, 2). Tidak boleh menipu orang, 3). Tidak boleh membunuh orang, 4). Tidak boleh berzina, 5). Tidak boleh berduaan dengan wanita bukan muhrim, 6). Tidak boleh melanggara aturan upacara adat, 7). Tidak boleh tidak kawin bagi yang sudah melahirkan bayi sebelum di aqad, 8). Tidak boleh menghina seseorang tanpa ada unsur, 9). Tidak boleh memutar balikan fakta (lidah) biar tidak disertai bukti, asal ada dua saksi yang kuat, misalnya dalam soal beli tanah, ikrar hibah, dan sebagainya, 10). Tidak boleh melangar batas wilayah yang telah ditentukan bersama.

3). Keunikan Adat dan Kesenian Tradisonal

Kebudayaan adalah sesuatu perilaku manusia, bahasa, kesenian, pakaian manusia serta adat istiadat suatu desa atau daerah yang diwarisi secara turun temurun bagi warga di desa atau daerah, dimana ia bertempat tinggal. Kebudayaan tradisional adalah sesuatu prilaku, bahasa, kesenian dan adat istiadat serta barang-barang atau benda yang sudah mencapai umur 65 tahun kertas, yang masih dilestarikan oleh generasi pewarisnya di suatu desa atau daerah tertentu. Berdasarkan hasil penelitian bahwa 153 desa yang ada di Kabupaten Bima ini, Desa Maria adalah desa yang terkaya dengan budaya tradisonal. Pada saat sekarang dan masih lestari antara lan :

1. Keseniannya : Tari mpa'a manca, Tari buja kadanda, Tari joget, Tail mpa'a sampan (tari lepi wei), Tari sagele, Tari wura bongi monca, Tari makatua, Jikirjikir yang terdiri dari 1). Jikir lo'i (jikir donggo mara), 2). Jikir tua (jikir mbojo), 3). Jikir kapanca, 4). Jikir hadrah dan 5). Jikir hatta

2. Benda-benda budaya yang terdiri dari 1). Pasanggerehan wawo, umurnya sudah 69 tahun, 2). Kantor jeneli wawo, umurnya sudah 69 tahun, 3). Lengge tradisional, umurnya sudah 250 tahun, 4). Seni rumah sanggar umurnya sudah 250 tahun

3. Adat-adat lain : 1). Nggahi panati, 2). Nggahi hengga kalambu, oleh ama ruka, 3). Jawa bahan ina ruka, 4). Tata cara pamaco, 5). Tata cara kalondo penganten siwe, 6). Tata cara toho dou ade paruga, 7). Tata cara toho tambo/jajan ade paruga, 8). Tata cara pembagian warisan, 9). Tata cara menjatuh sanksi kepada pelanggar adat. Dengan tujuh buah tari tradisional ditambah dua nyanyian dan lima buah zikir serta 9 tata cara adat tradisionalnya Desa Maria dapat dikatakan desa yang masih kaya dengan budaya tradisionalnya. Kemudian ditambah lagi dengan tempat-tempat bersejarah sebanyak 12 buah (tempat). Dengan data dan fakta di atas maka wajar juga desa maria disebut desa wisata atau desa budaya karena desa- 
desa tetangganya sebagai pendukung, seperti :

a). Desa Ntori dikenal dengan Tari Ntumbu

b). Desa Tarlawi dikenal tari kalero .

c). Desa Raba dikenal dengan zikir hadrahnya.

d). Desa Sambori dikenal dengan lengge tradisionalnya

e). Desa Pesa dikenal dengan karombo pesa dan doro ntanta wura

f). Desa Kambilo dikenal ncuhi kaliwo dan pindahan mesjid kamin ke Desa Kambilo duluannya dan sampai sekarang masih ada angkat masjid kamin dan pedang mesjid kamina serta biduannya.

\section{4). Keunikan Upacara Tradisonal}

Salah satu upacara yang unik di Desa Maria Wawo adalah upacara tradisional "Ampa Fare".Berikut merupakan definisi dari budaya ampa fare: 1). Ampa berarti menaikkan, 2). Fare berarti padi, 3). Lengge berarti lumbung padi, atau adat tradisional, 4). awo adalah sebuah nama kecamatan di Kabupaten Bima.Jadi "Upacara Adat Ampa Fare Di Lengge" merupakan sebuah kegiatan yang kontinyu pada setiap tahun yang dilakukan oleh Warga Desa Maria Kecamatan. Wawo Daerah Kab. Bima Propinsi Nusa Tenggara Barat. Desa Maria cukup dikenal di Kabupaten Bima karena masih banyak Upacara Adat yang masih lestari dilakukan oleh warga Masyarakat. Antara Lain : a). Upacara Adat Ampa Fare, b). Upacara Adat Ndoso Ro Suna, c). Upacara Adat Nikah Nenggu, d). Upacara Adat Wa'a Coi (Antar Mahar), e). Upacara Adat Tari Maka tua atau kata lainnya Upacara Adat Terima Pembesar Negeri.

Dari beberapa Upacara adat tersebut diatas harus disertai bebrapa jenis kesenian tradisionalnya antara lain : 1). Kesenian Tradisional "Tari Manga", 2). Kesenian Tradisional "Tari Buja Kananda", 3). Keseniai Tradisional "Wura Bongi Monca", 4). Kesenian Tradisional "Tari Segele", 5). Kesenian Tradisional "Rawa
Mbojo", 6). Kesenian Tradisional "Jikir Kapanca", 7). Kesenian Tradisional "Jikir Hadrah".

\section{b) Tingkat Aksesibilitas}

Tingkat aksesibilitas adalah tingkat kemudahan atau transportasi dalam mencapai objek Objek wisata Uma Lengge Desa Maria Wawo. Adapun tingkat aksesibilitas dapat diukur berdasarkan:

1. Kondisi Jalan

Kondisi jalan dalam hal ini ada dua yaitu kondisi jalan utama dan kondisi jalan setapak menuju objek. Kondisi jalan utama saat ini yang dari arah Kota Bima sangat bagus dan lebar jalan sudah memadai. Pada umumnya wisatawan yang berkunjung di objek ini sebagian besar membawa mobil sendiri, mobil sewaan (rent car), sepeda motor dan ada juga yang menggunakan jasa mobil angkutan bus dan ojek yang banyak tersedia. Akan tetapi, kondisi aksessibilitas menuju objek wisata Uma Lengge berupa jalan sempit yang tidak dapat dilewati kendaraan roda empat karena sangat sempit. Kondisi ini yang harus diperhatikan pemerintah untuk mengembangkan objek wisata Uma Lengge Maria Wawo.

2. Konstelasi Objek

Objek Wisata Uma Lengge Desa Maria Wawo mempunyai letak yang sangat strategis, karena sangat dekat dengan objek - objek wisata lain yang ada di kabupaten Bima seperti objek pemandian Oi Wobo yang berjarak beberapa ratus meter dari objek. Kabupaten Bima juga sangat kaya akan objek wisata Alam, seperti Pulau Ular di Kecamatan Sape, objek wisata Mutiara, dan beberapa objek yang sangat indah lain. Jadi keberadaan Objek wisata Uma Lengge Desa Maria Wawo memiliki konstelasi dengan objek-objek wisata lainnya. Dengan demikian untuk mencapai objek wisata Uma Lengge Desa Maria Wawo ini sekaligus dapat menikmati objek wisata lainnya dalam satu lintasan, apalagi 
bagi wisatawan mancanegara yang akan berkunjung ke pulau Komodo.

\section{c) Hasil Persepsi Masyarakat dan Wisatawan}

Hasil akhir persepsi dari masyarakat maupun wisatawan menunjukkan adanya dukungan yang positif terhadap pengembangan Uma Lengge Desa Maria Wawo sebagai sebuah desa wisata di Kabupaten Bima karena keunikan budaya dan tradisi yang terpelihara baik yang dimiliki serta tidak dimiliki oleh daerah lain di kabupaten Bima.

Upaya Strategi pengembangan objek wisata Uma Lengge desa Maria sebagai desa wisata andalan dengan kenunikan budaya di Kabupaten Bima adalah dengan melalui upaya peningkatan objek dan daya tarik wisata budaya, peningkatan promosi, informasi dan paket wisata serta peningkatan kualitas sumber daya manusia, pembinaan masyarakat setempat, serta perlunya dibangun sarana dan prasarana wisata di Uma Lengge Desa Maria Wawo .

Program dan kebijakan yang harus diterapkan di Uma Lengge Maria sebagai sebuah desa wisata andalan adalah meliputi: Mendorong pembangunan pariwisata ramah lingkungan.
Perlunya faktor-faktor pendukung yang harus tersedia di objek wisata Desa Wisata "Uma Lengge" Wawo yang terdiri dari: Keindahan alam khas pedesaan dan iklim, Sifat-sifat dari masyarakat sekitar dan kebudayaan, Fasilitas-fasilitas penginapan, reaksi dan pendidikan, Infrastruktur daerah, Tingkat pelayanan, fasilitas komersial dan pembelanjaan, sikap terhadap wisatawan serta kemudahan masuk daerah objek pariwisata. Selain itu, perlunya dukungan unsur-unsur sosial budaya yang harus tersedia di desa wisata wawo sebagai salah satu objek wisata budaya di Kabupaten Bima yang meliputi; kerajinan masyarakat lokal yaitu masyarakat Desa Maria harus ditonjolkan dan ditawarkan kepada wisatawan sebagai kerajinan khas asli daerah, bahasa sebagai bahasa asli daerah dalam hal ini adalah sebagian besar bahasa Wawo, Tradisi-tradisi dalam hal ini terkait dengan adat istiadat masyarakat Desa Maria sebagai daya tarik bagi wisatawan, Gastronomi atau makanan khas masayarakat Desa Maria harus diupayakan ada dan memberikan ciri tersendiri dengan makanan khas dari daerah lain, Keseniaan/musik masyarakat setempat.

\section{d) Analisis SWOT Potensi Masyarakat "Uma Lengge" Di Desa Maria Wawo}

Hasil analisis SWOT Potensi Uma Lengge di Desa Maria Sebagai Desa Wisata tergambar pada tabel berikut.

Tabel 1. Analisis SWOT Strategi Pengembangan Desa Wisata Wawo Sebagai Objek Wisata Budaya di Kabupaten Bima

\begin{tabular}{|c|c|c|c|c|c|c|}
\hline No & Variabel & & $\begin{array}{c}\text { Strength } \\
\text { (Kekuatan) }\end{array}$ & $\begin{array}{l}\text { Weaknesses } \\
\text { (Kelemahan) }\end{array}$ & $\begin{array}{c}\text { Oppotunities } \\
\text { ( Peluang ) }\end{array}$ & $\begin{array}{c}\text { Threats } \\
\text { ( Ancaman ) }\end{array}$ \\
\hline 1. & $\begin{array}{l}\text { Keadaan } \\
\text { Alam / } \\
\text { Panorama }\end{array}$ & $\overline{\text { a) }}$ & $\begin{array}{l}\text { Keindahan } \\
\text { panorama alam } \\
\text { pedesaan } \\
\text { Dapat melihat } \\
\text { nuansa alam } \\
\text { khas pedesaan } \\
\text { yang jauh dari } \\
\text { polusi } \\
\text { Dapat melalui } 3 \\
\text { sampai } 4 \text { objek }\end{array}$ & 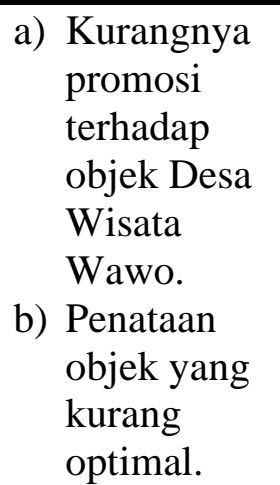 & 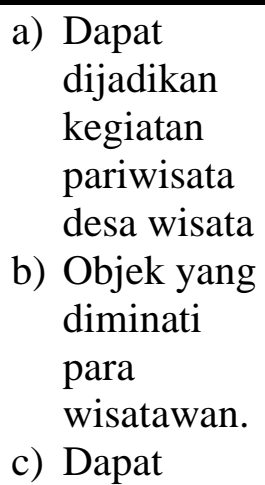 & $\begin{array}{l}\text { a) Degradasi } \\
\text { mutu } \\
\text { lingkungan } \\
\text { alam. } \\
\text { b) Terjadinya } \\
\text { polusi baik } \\
\text { udara, air, } \\
\text { tanah } \\
\text { maupun } \\
\text { suara. }\end{array}$ \\
\hline
\end{tabular}




\begin{tabular}{|c|c|c|c|c|c|c|c|}
\hline & & d) & $\begin{array}{l}\text { sekaligus. } \\
\text { Dapat melihat } \\
\text { aktifitas sehari- } \\
\text { hari masyarakat } \\
\text { desa. } \\
\text { Dapat melihat } \\
\text { cagar budaya } \\
\text { "Uma Lengge" } \\
\text { Rumah } \\
\text { Tradisional } \\
\text { Bima }\end{array}$ & & $\begin{array}{l}\text { Lingkungan } \\
\text { sekitar objek } \\
\text { yang kurang } \\
\text { bersih. }\end{array}$ & $\begin{array}{l}\text { dikembang } \\
\text { kan sebagai } \\
\text { wisata alam } \\
\text { dengan } \\
\text { perpaduan } \\
\text { wisata desa }\end{array}$ & \\
\hline 2. & $\begin{array}{l}\text { Kebudayaa } \\
\mathrm{n}\end{array}$ & b) & $\begin{array}{l}\text { Adanya budaya } \\
\text { Wawo yang } \\
\text { merupakan } \\
\text { budaya asli } \\
\text { kabupaten Bima } \\
\text { Kesenian } \\
\text { tradisional yang } \\
\text { ada di } \\
\text { masyarakat yang } \\
\text { dapat } \\
\text { dipertunjukkan } \\
\text { ditengah } \\
\text { kedatangan } \\
\text { wisatawan } \\
\text { Kehidupan } \\
\text { masyarakat } \\
\text { sebagai petani } \\
\text { sawah dan } \\
\text { ladang/tegalan }\end{array}$ & a) & $\begin{array}{l}\text { Belum } \\
\text { adanya } \\
\text { tempat } \\
\text { pementasan } \\
\text { dan calender } \\
\text { kesenian } \\
\text { yang jelas. } \\
\text { Masih } \\
\text { kurangnya } \\
\text { promosi dari } \\
\text { kualitas } \\
\text { produk. }\end{array}$ & $\begin{array}{l}\text { a) Pelestarian } \\
\text { budaya } \\
\text { Wawo. } \\
\text { b) Pelestarian } \\
\text { kesenian } \\
\text { tradisional } \\
\text { masyarakat } \\
\text { c) Peralihan } \\
\text { kehidupan } \\
\text { masyarakat } \\
\text { sebagai } \\
\text { petani } \\
\text { modern }\end{array}$ & $\begin{array}{l}\text { a) Terjadinya } \\
\text { komersialisa } \\
\text { si budaya. } \\
\text { b) Munculnya } \\
\text { persainagn } \\
\text { yang } \\
\text { mengarah } \\
\text { pada } \\
\text { persaingan } \\
\text { tidak sehat. } \\
\text { c) Pergeseran } \\
\text { kehidupan } \\
\text { masyarakat } \\
\text { yang } \\
\text { cenderung } \\
\text { ingin } \\
\text { meniru. }\end{array}$ \\
\hline 3. & $\begin{array}{l}\text { Aksesibilit } \\
\text { as }\end{array}$ & $\begin{array}{l}\text { b) } \\
\text { c) }\end{array}$ & $\begin{array}{l}\text { Pada jalur } \\
\text { strategis yang } \\
\text { berada di jalur } \\
\text { wisatawan } \\
\text { menuju Labuan } \\
\text { Bajo dengan } \\
\text { Pulau } \\
\text { Komodonya } \\
\text { Konstelasi objek } \\
\text { Kondisi jalan } \\
\text { utama yang } \\
\text { cukup memadai } \\
\text { Dapat dijangkau } \\
\text { dengan } \\
\text { kendaraan } \\
\text { bermotor }\end{array}$ & a) & $\begin{array}{l}\text { Jarak dan } \\
\text { waktu } \\
\text { tempuh dari } \\
\text { pusat kota } \\
\text { cukup dekat } \\
\text { Sarana jalan } \\
\text { menuju } \\
\text { objek yang } \\
\text { tidak teraspal } \\
\text { bagusl } \\
\text { Belum } \\
\text { adanya } \\
\text { angkutan } \\
\text { khusus } \\
\text { menuju ke } \\
\text { objek }\end{array}$ & $\begin{array}{l}\text { a) Perbaikan } \\
\text { kualitas } \\
\text { jalan yang } \\
\text { sebagian } \\
\text { rusak dari } \\
\text { arah Kota } \\
\text { Bima } \\
\text { b) Dapat } \\
\text { meningkatk } \\
\text { an jumlah } \\
\text { kunjungan } \\
\text { wisatawan }\end{array}$ & $\begin{array}{l}\text { a) Terjadinya } \\
\text { polusi } \\
\text { akibat } \\
\text { banyaknya } \\
\text { wisatawan } \\
\text { yang } \\
\text { menggunak } \\
\text { an } \\
\text { kendaraan } \\
\text { bermotor }\end{array}$ \\
\hline 4. & $\begin{array}{l}\text { Sumber } \\
\text { daya } \\
\text { Manusia }\end{array}$ & a) & $\begin{array}{l}\text { Jumlah } \\
\text { penduduk } \\
\text { produktif yang }\end{array}$ & a) & $\begin{array}{l}\text { Ketrampilan } \\
\text { pariwisata } \\
\text { kurang. }\end{array}$ & $\begin{array}{l}\text { a) Tersediany } \\
\text { a SDM } \\
\text { yang cukup }\end{array}$ & $\begin{array}{l}\text { a) Munculnya } \\
\text { tenaga kerja } \\
\text { luar masuk }\end{array}$ \\
\hline
\end{tabular}




\begin{tabular}{|c|c|c|c|c|c|c|c|}
\hline & & & $\begin{array}{l}\text { cukup banyak } \\
\text { Dukungan dari } \\
\text { masyarakat } \\
\text { tentang } \\
\text { pengembangan } \\
\text { objek wisata } \\
\text { "Uma Lengge" } \\
\text { di Desa Maria } \\
\text { Wawo }\end{array}$ & b) & $\begin{array}{l}\text { Kurangnya } \\
\text { pengetahuan } \\
\text { masyarakat } \\
\text { tentang arti } \\
\text { penting } \\
\text { pariwisata. } \\
\text { Belum } \\
\text { adanya sadar } \\
\text { wisata dari } \\
\text { masyarakat } \\
\text { Belum } \\
\text { adanya } \\
\text { tenaga medis } \\
\text { di objek } \\
\text { Desa Wisata } \\
\text { "Uma } \\
\text { Lengge" } \\
\text { Wawo. }\end{array}$ & \begin{tabular}{|l} 
potensial \\
untuk \\
menjadi \\
tenaga \\
kerja yang \\
terampil. \\
b) Membuka \\
lapangan \\
kerja baru \\
c) Pemberday \\
aan \\
masyarakat \\
lokal. \\
d) Meningkat \\
kan \\
pendapatan \\
masyarakat \\
.
\end{tabular} & $\begin{array}{l}\text { jika tidak } \\
\text { mendapatka } \\
\mathrm{n} \\
\text { penanganan } \\
\text { yang tepat } \\
\text { dan cepat. } \\
\text { b) Timbulnya } \\
\text { masalah } \\
\text { sosial di } \\
\text { masyarakat } \\
\text { c) Kurang } \\
\text { optimalnya } \\
\text { peranan } \\
\text { masyarakat } \\
\text { dalam } \\
\text { mendukung } \\
\text { perkembang } \\
\text { an } \\
\text { pariwisata }\end{array}$ \\
\hline 5. & $\begin{array}{l}\text { Fasilitas } \\
\text { Pendukung }\end{array}$ & a) & $\begin{array}{l}\text { Sudah } \\
\text { tersediamya } \\
\text { sarana dan } \\
\text { prasarana } \\
\text { pariwisata yang } \\
\text { cukup memadai } \\
\text { Fasilitas parkir, } \\
\text { rumah makan, } \\
\text { musholla, MCK, } \\
\text { dll }\end{array}$ & $\begin{array}{l}\text { a) } \\
\text { b) }\end{array}$ & $\begin{array}{l}\text { Kurangnya } \\
\text { permodalan } \\
\text { Masih } \\
\text { diperlukan } \\
\text { perbaikan } \\
\text { fasilitas } \\
\text { pendukung } \\
\text { Fasilitas } \\
\text { parkir yang } \\
\text { perlu } \\
\text { diperluas. }\end{array}$ & $\begin{array}{ll}\text { a) } & \text { Membuka } \\
\text { peluang } \\
\text { investor } \\
\text { untuk } \\
\text { menanamk } \\
\text { an } \\
\text { modalnya }\end{array}$ & $\begin{array}{l}\text { a) Terjadinya } \\
\text { kerusakan } \\
\text { lingkungan }\end{array}$ \\
\hline
\end{tabular}

Sumber : Diolah dari hasil penelitian, 2018

\section{KESIMPULAN}

Potensi Desa Maria Wawo dengan keunikan budaya Uma Lenggenya sebagai salah satu objek wisata budaya di Kabupaen Bima adalah terdiri dari potensi fisik yang meliputi keunikan budaya Uma Lengge, kebududayaan dan kesenian yang terus hidup dan lesatari ditengah masyarakat dengan dukungan sanggarsanggar seni tradisional, pemandangan Alam khas pedesaan kawasan puncak yang sejuk dan dingin, serta dukungan dari objek wisata penunjang lainnya seperti Oi Wobo yang berdekatan dengan objek. Sedangkan potensi nonfisiknya adalah kebudayaan khas desa maria Wawo, kesenian tradisional khas beserta upacara adatnya yang terus terpelihara baik, kegiatan masyarakat dan aktivitas masyarakat desa Maria Wawo yang unik. Sedangkan dukungan fasilitas penunjang kegiatan pariwisata yang sudah tersedia di objek wisata Uma Lengge Desa Maria Wawo adalah lokasi Uma Lengge yang sudah dipugar keliling sehingga tertata baik sebagai sebuah cagar budaya, toilet/MCK dan fasilitas peribadatan berupa musholla.

Hasil akhir persepsi dari masyarakat maupun wisatawan menunjukkan adanya dukungan yang positif terhadap pengembangan Uma Lengge Desa Maria Wawo sebagai sebuah desa wisata di Kabupaten Bima karena keunikan budaya 
dan tradisi yang terpelihara baik yang dimiliki serta tidak dimiliki oleh daerah lain di kabupaten Bima.

Dilihat dari hasil analisis SWOT yang terdiri dari 5 Variabel diperoleh bahwa 4 variabel yang dianalisis mempunyai porsi yang lebih dominan, yaitu keindahan alam, kebudayaan, tingkat aksesibilitas dan sarana pendukung sedangkan 1 variabel lainya yang merupakan kelamahan adalah sumber daya manusia sehingga memerlukan penanganan yang cepat dan tepat.

\section{SARAN}

Untuk kemajuan dan pengembangan potensi Uma Lengge di Desa Wisata Maria Kecamatan WawoKabupaten Bima adalah sebagai berikut. 1). Untuk mencapai pengembangan potensi yang optimal diperlukan kerja sama yang baik dari berbagai pihak, Pemerintah daerah, masyarakat, swasta ( pebisnis ) maupun LSM serta tidak ketinggalan adalah wisatawan sebagai pangsa pasar 2). Peningkatan fasilitas seperti sarana transportasi, sarana jalan, sarana telekomunikasi, tempat pertunjukan kesenian dan informasi, 3). Penyediaan sumber daya manusia yang berkulitas dan memadai dalam bidang pariwisata dan konservasi, melalui pendidikan dan pelatihan di bidang pariwisata dan konservasi, 4). Promosi yang lebih intensif dan bekerja sama dengan biro perjalanan wisata, pemerintah, pengelola, masyarakat dan lembaga kepariwisataan lainya, 5). Perlunya ditumbuhkan rasa sadar bagi masyarakat sekitar dalam menjaga kebersihan lingkungan objek wisata Desa Wisata Wawo juga bagi wisatawan agar mau dan bersedia ikut menjaga kelestarian alam pedesaan.

\section{DAFTAR PUSTAKA}

Davidson, Rob, Maitland, Robert, 1997. Tourism Destination, Hodder \& Stoughton, British.

Inskeep, Edward. 1997. Tourism Planning An Integrated and Sustainable Development Approach.

Pendit, Nyoman S., 1990, Ilmu Pariwisata Sebuah PengantarPerdana. Pradnya Paramita: Jakarta

Pusat Studi Pariwisata Universitas Gadjah Mada. 2003. Rencana Induk Pengembangan Pariwisata Daerah (RIPPDA) Kabupaten Sumba Barat . Jogyakarta.

Santosa, Setyanto. 2002. Makalah Pengembangan Pariwisata Indonesia.

Swardana. 2005. Pengembangan Desa Wisata Di Bali. Jurnal Pariwisata Universitas Udayana: Bali

Tri Sakti. 2003. Jurnal Pariwisata. Jakarta: LPPM Tri Sakti

UNDP and WTO. 1981. Tourism

Development Plan for Nusa

Tenggara, Indonesia. Madrid: World Tourism Organization)

Wahyudi, Hendro. 2003. Prospek Pengembangan Kawah Ijen Sebagai Objek Wisata Alam di Kabupaten Bima. Jember: Penelitian Dikti Akademi Pariwisata Muhammadiyah Jember.

Nuryanti, Wiendu. 1993. Concept, Perspective and Challenges, PariwisataBudayaYogyakarta.

Gadjah Mada University Press: Yogyakarta

1993http://id.wikipedia.org/wikiDesa

Wisata

Yoeti, Oka, 1997, Perencanaan dan Pengembangan Pariwisata. Pradnya Paramita: Jakarta 